\title{
Optimal Arable Crop Plan and Child Farm Labour Reduction in Rural Households of Ogun State, Nigeria
}

\author{
M. U. Agbonlahor ${ }^{1}$, R. Adeyemo ${ }^{2}$,A. S. Bamire ${ }^{2}$ and S. B. Williams ${ }^{2}$ \\ 1. Department of Agricultural Economics, University of Agriculture, Abeokuta, Nigeria \\ E-mail:magbonlahor@gmail.com \\ 2. Department of Agricultural Economics, Obafemi Awolowo University, Ile-Ife, Nigeria
}

KEYWORDS Child Farm Labour. Rural Households. Optimal Crop Plan

\begin{abstract}
The study was carried out to model an optimal arable crop plan that minimizes child farm labour use in Ogun State, Nigeria. A multistage sampling technique was used to select a total of 400 rural households from the State. The household survey involves an interview of 594 children, 400 household heads and a focus group discussion section in four locations. The data collected were analyzed using both descriptive and inferential statistics in line with the study objectives. The linear programming model was used to develop an optimal arable crop farm that maximizes economic returns to the farmers while simultaneously allowing for maximum school attendance and involvement. The optimal farm model revealed that a restructuring of the crop enterprise plan could increase the annual farm income by about 15.3 percent, while at the same time minimizing the child farm labour involvement in the State. The study recommends that reducing child labour, will require facilitating access to credit to the resources-poor rural households. Also, that government should provide assistance to arable crop farmers in the areas of subsidizing the costs of production inputs (seeds, tractor hiring, fertilizers and other agrochemicals), and that research efforts should be geared towards developing simple, affordable, and adaptable machines/implements, and other farm labour-saving devises.
\end{abstract}

\section{INTRODUCTION}

Agricultural production is the mainstay of the Nigerian economy; considering the fact that over 80 percent of the economically active populations are involved in agricultural production and that over 90 percent of the food consumed in the country is from the local agricultural production. It is the second largest earner of foreign exchange; next to the nonsustainable petroleum sector, and also it provides a ready market for industrial products. (Ayanwale 2002).

Children represent the future of human race. In the less developed countries, those who grow to school age grow up under a blanket of diseases, malnutrition, lack of food and inadequate schooling, in these circumstances children drift into the labor market. It is estimated that world wide millions of children work, although the world generally agreed that it is unacceptable for children under specific age to do certain type of work. International Labor Organization, ILO (2002) set that child labour is defined as labor furnished by persons below their official minimum age of employment, which is 15 .

The Millennium Development Goals (MDGs) of the United Nations, for the reasons highlighted above, encapsulate increasing resources productivity in agriculture as part of its set objectives with key measurable indicators. It recommends
States to embark on projects that target the rural areas, where the bulk of agricultural activities take place; and in doing this must as of a necessity first explore potential impediments to growth and development of the rural areas.

CBN (2004) report on the distribution and profile of poverty in Nigeria indicates that the rural areas are worse off, and that the propensity of a household falling below the poverty line is higher in the rural areas. The report also indicated that rural households are of low educational level which dovetails into low incomes. In rural economies, the more equal the incomes and assets, the more powerful the growth effect in poverty reduction. As inequality increases; as a result of poor human capital development from child labour, the linkage of growth to the poor weakens, and in the most unequal of rural economies, growth tends to bypass poor people completely. The quality of rural development is, thus, a basic determinant of the quality of the future social development of a country. For the purpose of this study, child farm labour excludes involvement in house chores or after school paid or unpaid activities. Child labour is defined as any farm activity in which children (less than 18 years) are involved that warrants loss in school days and/or time. It is defined to mean all farms or farm related activities that the opportunity cost is schooling for children between 7-17 years. 


\section{Problem Statement}

Developing economies are characterized by a low level of human capital development, which not only impedes present but also future productivity. In the light of this, Glick and Sahn (2000) reported that the elimination/reduction of human capital development impediments is a sure way of promoting economic growth and the elimination of poverty in developing countries. Table 1 shows the distribution of child labour in the world economies. The proportion of child labourers to the total child population is highest in Sub Saharan Africa.

The absence of high technical input (human knowledge and technologies), which is a major precursor of low productivity has been described as the outcomes of promoting child labour at the detriment of educational development.

The emerging evidences on the magnitude and spread of child labour especially in farm households, has again beam the lights on the issue of labour productivity in agricultural production. The question now being highlighted bears on a present decision that affects a future outcome. Child labour that affects the intellectual

Table 1: Distribution of children in economic activities by region in year 2000

\begin{tabular}{|c|c|c|c|}
\hline $\begin{array}{l}\text { Economic } \\
\text { activities }\end{array}$ & $\begin{array}{c}\text { Levels } \\
\text { (Millions) }\end{array}$ & $\begin{array}{l}\text { \% of } \\
\text { total }\end{array}$ & $\begin{array}{l}\text { \% in Total } \\
\text { child } \\
\text { population }\end{array}$ \\
\hline 5-14 Years Old & 211 & & 17.6 \\
\hline $\begin{array}{l}\text { Industrialized } \\
\text { Economies }\end{array}$ & 2.5 & 1 & 2 \\
\hline $\begin{array}{l}\text { Transition } \\
\text { economies }\end{array}$ & 2.4 & 1 & 4 \\
\hline Asia and the Pacific & 127.3 & 60 & 19 \\
\hline $\begin{array}{l}\text { Latin America \& } \\
\text { Caribbean }\end{array}$ & 17.4 & 8 & 16 \\
\hline Sub Saharan Africa & 48 & 23 & 29 \\
\hline $\begin{array}{l}\text { Middle East and } \\
\text { North Africa }\end{array}$ & 13.4 & 6 & 15 \\
\hline 15-17 Years Old & 140 & & 42.4 \\
\hline $\begin{array}{l}\text { Industrialized } \\
\text { Economies }\end{array}$ & 115 & 8.1 & 31.3 \\
\hline $\begin{array}{l}\text { Transition } \\
\text { Economies }\end{array}$ & 6.0 & 4.2 & 29.1 \\
\hline Asia and the Pacific & 86.9 & 61.7 & 48.4 \\
\hline $\begin{array}{l}\text { Latin America \& } \\
\text { Caribbean }\end{array}$ & 10.3 & 7.3 & 25.0 \\
\hline Sub Saharan Africa & 18.1 & 12.8 & 44.8 \\
\hline $\begin{array}{l}\text { Middle East and } \\
\text { North Africa }\end{array}$ & 7.5 & 5.3 & 31.8 \\
\hline Total & 351 & & 23 \\
\hline
\end{tabular}

Source: ILO (2002) development of the child, though satisfying an immediate (short termed) need, will in a future period negatively influence the productivity of the factor of production (labour). In the light of these, the study will seek to answer the following research questions:

- What households, child and community variables/factors determine the decision to involve in child farm labour?

- What is the region specific optimal arable crop model that maximizes economic returns and minimizes child farm labour use intensity

\section{Study Objective}

The broad objective of the study is to carry out an assessment of the determinants of child farm labour in rural households in Ogun state, Nigeria.

Specifically, the study will:

1. analyze the socio-demographic characteristics of children that are engaged in farm labour

2. determine an optimal farm model that maximizes economic returns from arable crop farming while at the same time minimizing child farm labour use

\section{STUDY AREA}

The study was carried out in the rural households of Ogun State, Nigeria. Ogun State commonly known as the gateway state is in South-Western Nigeria, and lies within the tropics. It is bounded to the West by Benin Republic; to the South by Lagos State and the Atlantic Ocean; to the East by Ondo State; and to the North by Oyo and Osun States. It was carved out from the old western region in 1976. It has an estimated land area of 16,409.26 square kilometers of which over 70 percent are suitable for arable crop production. The estimated human population is $2,338,570$ (NPC 2000), with a projected 2005 estimates of $3,214,161$ people (CBN 2005). Agricultural food crop production is the economic backbone of the State though cash crop production, fisheries and forestry is also common.

\section{Data and Sampling Techniques}

A total of 400 households were selected for the survey using the multistage sampling 
approach. The four (4) zones of the Ogun State Agricultural Development Programme (OGADEP) were used as the first sampling stratum. The four zones are the Abeokuta, Ikenne, Ijebu and Ilaro zones. Simple random sampling was used to select a total of hundred (100) villages, twentyfive (25) from each zone, after urban towns were isolated from the sample frame. The second stage of selection was the purposive selection of four (4) households from each of the selected community and 10 households were then purposively selected from each community.

\section{Analytical Technique}

The Linear Programming (LP) model is specified to optimize a production objective subject to some sets of production constraints (factors of production). The model is specified thus:

$\operatorname{Max} . Z: \Sigma a_{i} x$

Subject to: ${ }^{i} \Sigma_{i j} \leq G_{j}$

Where, $\mathrm{a}_{\mathrm{i}}=$ The Gross Margin (GM) of the ith crop enterprise

$\mathrm{X}_{\mathrm{i}}=$ Size of the ith crop enterprise (ha)

$\mathrm{b}_{\mathrm{ij}}=\mathrm{jth}$ activity level of the ith crop enterprise
$\mathrm{G}_{\mathrm{j}}=$ household's maximum or avalaible levels of $\mathrm{jth}$ activity/ input

The input matrix of the LP model to be optimized was specified by incorporating an activity level for minimal use of child farm labour in the enterprise production (levels that doesn't interfere with or diminish the school periods), the time allowance modeled in the plan was for an involvement of less than 4 hours per day. An optimal farm plan was modeled in the study for the arable crop farms. The linear programming model was used to optimize the plan that returned the highest economic benefit while at the same time minimizing the use of child farm labour, subject to the rural household's production constraint.

The farm plan was modeled based on the hypothesis that the crop production system adopted by the households was a major reason for the incidence of child farm labour. The model dual objectives were both for highest economic returns (profit maximizing goal) and a reduction in child farm labour use, in seeking an arable crop mix that takes into consideration the school time of farm children. The school time allowances made was for a minimum of 30 hours on week days in calculating the available children work days.

Table 2: Socio-demographic characteristics of children interviewed

\begin{tabular}{|c|c|c|c|c|c|c|}
\hline $\begin{array}{l}\text { Socio-demographic } \\
\text { characteristics }\end{array}$ & Frequency & Percent & Mean & Min. & Max. & Standard \\
\hline \multicolumn{7}{|l|}{$\operatorname{Sex}$} \\
\hline Male & 384 & 64.6 & $\mathrm{Na}$ & $\mathrm{Na}$ & $\mathrm{Na}$ & $\mathrm{Na}$ \\
\hline Female & 210 & 35.4 & & & & \\
\hline \multicolumn{7}{|l|}{ Age Range } \\
\hline $7-10$ years & 142 & 23.9 & & & & \\
\hline $11-13$ years & 193 & 32.5 & 12.8 & 7 & 17 & 2.51 \\
\hline $14-17$ years & 259 & 43.6 & & & & \\
\hline \multicolumn{7}{|l|}{ Child Living Status } \\
\hline Child of household head & 410 & 69.0 & $\mathrm{Na}$ & $\mathrm{Na}$ & $\mathrm{Na}$ & $\mathrm{Na}$ \\
\hline Not child of household head & 184 & 31.0 & & & & \\
\hline \multicolumn{7}{|l|}{ Mothers' Status } \\
\hline Mother resident & 385 & 64.8 & $\mathrm{Na}$ & $\mathrm{Na}$ & $\mathrm{Na}$ & $\mathrm{Na}$ \\
\hline Mother not resident & 209 & 35.2 & & & & \\
\hline \multicolumn{7}{|c|}{ Highest Educational Level of Child (yrs) } \\
\hline Primary 3 & 59 & 9.9 & & & & \\
\hline Primary 4 & 49 & 8.3 & & & & \\
\hline Primary 5 & 94 & 15.8 & $6.3 \mathrm{yrs}$ & $2 \mathrm{yrs}$ & $10 \mathrm{yrs}$ & 2.94 \\
\hline Primary 6 & 103 & 17.3 & & & & \\
\hline JSS 1 & 93 & 15.7 & & & & \\
\hline JSS 2 & 86 & 14.5 & & & & \\
\hline JSS 3 & 87 & 14.6 & & & & \\
\hline SSS 1 & 23 & 3.9 & & & & \\
\hline \multicolumn{7}{|l|}{ Schooling Status } \\
\hline Child in school & 520 & 87.5 & $\mathrm{Na}$ & $\mathrm{Na}$ & $\mathrm{Na}$ & $\mathrm{Na}$ \\
\hline Child not in School & 74 & 12.5 & & & & \\
\hline
\end{tabular}

Source: Analysis of Field Survey (2005) Na. Not Applicable 


\section{Households' Characteristics and Child's Farm Labour Distribution}

The age range shows that most (about 44 percent) of the children interviewed for the study are within the age range of $14-17$ years. The mean age of the children was found to be $12.88 \pm 2.51$ years. The range of household size also revealed that majority (about 94 percent) of the children is from households with 4-12 persons per household. However, the mean household size was found to be $8.35 \pm 2.32$ persons per household, indicating that the average household in the study area has large families, Table 2.

The results also revealed that majority (about 75 percent) of the children interviewed were not involved in other economic activities apart from farming. This may be due to the non-availability of other income earning activities apart from farm and agriculturally related works in the rural areas. On the years of involvement in farm work, the study shows that majority (about 60 percent) of the children, have been involved in farm work for a minimum of 5 years. The mean years of involvement in farm work was 7.6 years. This may be due to the fact that, farm activities in the area are taken as an integral part of the family livelihood and members are easily and quickly integrated into it as shown in Table 3.

The analysis on the proportion of weekly school time spent on the farm activities by the children as a measure of child farm labour participation intensity is also presented in the table. The result revealed that the average hours spent on farm work of the weekly school hours (30 hrs) was about 5.26 hours. The implication of this distribution is that though there is regular school attendance (in terms of days/week), there is however a consistent rate of sacrifice of school time hours to farm work. The outcome of the farm work effect on school time as presented provides an understanding of the children performance

Table 3: Household farm and child's farm work distribution

\begin{tabular}{|c|c|c|c|c|c|c|}
\hline Farm and work characteristics & Frequency & Percent & Mean & Min. & Max. & Std. Dev. \\
\hline \multicolumn{7}{|l|}{ Farm Size } \\
\hline$<0.50$ ha & 134 & 22.6 & 0.93 & 0.23 & 2.60 & 0.6 \\
\hline $0.50-1.00$ & 276 & 46.5 & & & & \\
\hline ha1.01-1.50 & 111 & 18.7 & & & & \\
\hline ha1.51-2. 00ha & 33 & 5.6 & & & & \\
\hline$>2.00 \mathrm{ha}$ & 40 & 6.7 & & & & \\
\hline \multicolumn{7}{|l|}{ Crop Enterprises/Mix } \\
\hline Cassava/pepper & 36 & 6.1 & & & & \\
\hline Cassava/yam & 115 & 19.4 & $\mathrm{Na}$ & $\mathrm{Na}$ & $\mathrm{Na}$ & $\mathrm{Na}$ \\
\hline Maize/cassava & 161 & 27.1 & & & & \\
\hline Maize/cassava/pepper & 26 & 4.4 & & & & \\
\hline Maize/cassava/yam & 59 & 9.9 & & & & \\
\hline maize/vegetables & 13 & 2.2 & & & & \\
\hline Maize/yam/vegetables & 222 & 20.6 & & & & \\
\hline Sole yam & 19 & 3.2 & & & & \\
\hline Yam/pepper & 43 & 7.2 & & & & \\
\hline \multicolumn{7}{|c|}{ Other Economic Activities Apart from Farming } \\
\hline Not involved & 448 & 75.4 & $\mathrm{Na}$ & $\mathrm{Na}$ & $\mathrm{Na}$ & $\mathrm{Na}$ \\
\hline Involved & 146 & 24.6 & & & & \\
\hline \multicolumn{7}{|c|}{ How Long has Child been on Farm Work? } \\
\hline$<3$ years & 33 & 5.6 & 7.6 & 1 & 12 & 2.09 \\
\hline $3-5$ years & 33 & 5.6 & & & & \\
\hline$>5$ years & 354 & 59.6 & & & & \\
\hline \multicolumn{7}{|c|}{ Estimates of Farm Work Value on Family Farm (Naira/Week) } \\
\hline$<\mathrm{N} 100$ & 55 & 9.3 & 205.2 & 80 & 1287 & 116 \\
\hline N100-N150 & 121 & 20.4 & & & & \\
\hline N151-N200 & 130 & 21.9 & & & & \\
\hline N201-N250 & 45 & 7.6 & & & & \\
\hline N251-N300 & 25 & 4.2 & & & & \\
\hline$>\mathrm{N} 300$ & 218 & 36.7 & & & & \\
\hline \multicolumn{7}{|c|}{ Does the Child Works in Other Farms Apart from Family's } \\
\hline No & 526 & 88.5 & $\mathrm{Na}$ & $\mathrm{Na}$ & $\mathrm{Na}$ & $\mathrm{Na}$ \\
\hline Yes & 68 & 11.4 & & & & \\
\hline
\end{tabular}

Source: Analysis of Field Survey (2005) 
and academic development as a result of their farm involvement. Anyanwale (2000) in a similar study in Nigeria, found out that an average of 7.55 hours of school time is spent weekly on farm activities and that, farm involvement was the reason for about 35.9 percent lateness to school by the children. Azer (1999) in a similar study in Egypt also found out that involvement of the child in farm activities can result to as much as 25 percent of total absence from school.

\section{The Optimum Arable Crop Model}

For the dual objectives maximizing model the input matrix (Table 4), used for the optimization in interactions had 8 arable crops as enterprise variables for selection, and 5 production constraints.

The arable crops included in the model were selected as crops that were cultivated by at least 30 percents of the households. This was used as the selection criterion to give the model a statewide focus. The crops included for selection are fruits vegetables (Fv) which as indicated earlier are okra, pepper, melon and tomatoes; leafy vegetables (Lv); yam (Ym); cassava (Cv); Groundnut (Gn); Cocoyam (Cy); Maize (Mz) and Rice (Rc).

The production constraints are land, adult male and female labour, children labour supply and capital. Capital as a factor of production in the model was calculated as the total variable cost less the cost of family labour as adopted by Ogunfowora (1974), Celtin (1992), Okoruwa (1994) and Anya (2003). The objective function was specified to maximize the Total Gross Margin (TGM) from the selected crops per hectare. The technical co-efficient for each of the enterprise modeled were based on averages for each of the production constrain; except for land (ha) incorporated as a choice condition for the

Table 4: Modeled enterprises and gross margin (naira/ha)

\begin{tabular}{lcc}
\hline Crop & Variable & Gross $\operatorname{margin}\left(\mathrm{N}^{\prime} \mathrm{OOO}\right)$ \\
\hline Fruits vegetable & $\mathrm{Fv}$ & 30.62 \\
Leafy vegetables & $\mathrm{Lv}$ & 30.46 \\
Yam & $\mathrm{Ym}$ & 86.52 \\
Cassava & $\mathrm{Cv}$ & 52.14 \\
Groundnut & $\mathrm{Gn}$ & 18.44 \\
Cocoyam & $\mathrm{Cy}$ & 21.71 \\
Maize & $\mathrm{Mz}$ & 39.55 \\
Rice & $\mathrm{Rc}$ & 41.72 \\
\hline
\end{tabular}

Source: Summary statistics of field data (2005) enterprises. The constraints maximum (right hand side maximum), is the overall average (across enterprises) to indicate the maximum limits that is available for the plan for each of the production constraint. This as observed by Celtin (1992) is to ensure that the resulting plan is within the feasible region of the average farmer in the state.

The result of the Linear Programming analysis for the input matrix specified above is shown in Table 5.

Table 5: The basic farm plan

\begin{tabular}{lcccc}
\hline $\begin{array}{c}\text { Activities } \\
\text { selected }\end{array}$ & $\begin{array}{c}\text { Units } \\
\text { (Ha) }\end{array}$ & $\begin{array}{c}\text { Contribu- } \\
\text { tions } \\
\text { (Naira) }\end{array}$ & $\begin{array}{c}\text { Activities } \\
\text { not in } \\
\text { basic } \\
\text { solution }\end{array}$ & (Naira) \\
\hline $\begin{array}{l}\text { Fruits } \\
\text { Vegetables }\end{array}$ & 0.15 & 4593.29 & $\begin{array}{l}\text { Leafy } \\
\text { Vegetables }\end{array}$ & 5164.89 \\
Yam & 0.41 & 35482.21 Groundnut & 40189.18 \\
Cassava & 0.20 & 11935.21 Cocoyam & 35708.64 \\
Maize & 0.22 & 8658.52 Rice & 46838.79 \\
& \multicolumn{4}{c}{ Maximized Objective N60669.23 } \\
\hline
\end{tabular}

Source: Summary statistics of data (2005)

Four (4) crops were selected in the basic solution; these are maize, yam, cassava and fruits - vegetable in the decreasing order of scale. The model selection for the optimal plan and the scales are; maize (0.42ha), yam (0.21 ha), cassava (0.20ha) and fruits vegetables (0.15ha). The maximized objective function (TGM) from the iteration process is ${ }^{1} \forall 60669.23$, The optimal farm plan specifications for enterprise choice and scale were found to result to a higher return than the State' average (N52602.11) from arable crop production. The model resulted to a 15.3 percent increase in the Gross Margin (GM) for the average arable crop farm in the State. Apart from the better economic return the model will also ensure the reduction of child farm labour to the level to allow full school time involvement in schooling.

The optimal farm plan for the selected enterprise scales also illustrates the opportunity cost of the enterprises. The opportunity cost is indicated for non-selected enterprise. The opportunity cost is the penalty for producing non-selected crops. As evident from Table 6, while the greatest penalty (opportunity cost) is for rice production (loss of $\mathrm{N}$ 46838.79) the least penalty is for leafy-vegetables (N5164.8) the implication of this is that, forcing a unit (1ha) of rice and leafy vegetables into the plan will result to a reduction of the TGM by $\mathrm{A} 46838.7$ and 
Table 6: Optimal farm plan resources status

\begin{tabular}{|c|c|c|c|}
\hline Resource & Status & $\begin{array}{c}\text { Shadow price } \\
\text { (Naira) }\end{array}$ & $\begin{array}{l}\text { Slack/ } \\
\text { surplus }\end{array}$ \\
\hline $\begin{array}{l}\text { Farm land (ha) } \\
\text { Adult male }\end{array}$ & Tight & 30782.79 & 0 \\
\hline $\begin{array}{l}\text { labour (md) } \\
\text { Adult female }\end{array}$ & Loose & 0 & 106.38 \\
\hline labour (md) & Loose & 0 & 139.92 \\
\hline Children labour (md) & Tight & 3809.91 & 0 \\
\hline $\begin{array}{r}\text { Capital }\left(\mathrm{N}^{\prime} 000\right) \\
\text { Maximized }\end{array}$ & $\begin{array}{l}\text { Tight } \\
\text { Objective }\end{array}$ & $\begin{array}{ll} & 860.18 \\
\text { e } & \mathrm{N} 60669.23\end{array}$ & 0 \\
\hline
\end{tabular}

Source: Summarized LP result (2005)

A5164.8 respectively. The penalty will decrease for rice, groundnut, cocoyam and leafy vegetables in that order. The greatest penalty of the plan from rice production corroborates the findings of Okuneye (1995) and Oloruntimilehin (2000) who found that for rice production to be profitable in the state, there has to be a relaxation efforts (input subsidies and assess to credits) in the production constraints.

\section{CONCLUSION}

The study revealed that the present scale (subsistence) and arable crops enterprises combinations were also important contributory factors to child farm labour in the state. It was found out that the resources-poor farmers utilize mainly home-produced resources/farm inputs, and family labour for their labour intensive production. The linear programming model farm plan indicated that, even with the present farm production resource regime, it is possible to restructure the arable crops production plan in such a way as to increase economic returns by about 15.3 percent while at the same time minimizing child farm labour.

\section{REFERENCES}

Anya OA 2003. Economic development in Nigeria. A lead paper presented at the National Economic Summit, Abuja, June 2003.

Ayanwale BA 2002. Family investment in the Education of Children and Adolescents in Rural Osun State, Nigeria. In: Issues in African Rural Development Monograph Series. No. 21 Winrock International, P. 9

Azer A 1999. Child Labour in Egypt. National Center for Social and Criminal Research UNICEF Report. New York: UNICEF, P. 5

Basu K 2002. The Global Child Labour Problem: What do we know and what can we do? The World Bank Economic Review 17(2): 109.

Blunch N, Verner D 2001. Revisiting the link between Poverty and Child Labour: The Ghanian Experience. Centre for Labour Market and Social Research Working paper 01-03. Aarhus Denmark, P. 6 .

Brown LR, Yohannes Y, Webb P 1994. Rural labourintensive public works: impacts of participation on preschooler nutrition: evidence from Niger. American Journal of Agricultural Economics, 76 (5): 1213-1218.

CBN 2004. Central bank of Nigeria Annual Report and Statistical Bullettin. CBN Report Abuja, Nigeria: CBN

Celtin B 1992. Determination of optimal production patterns on farms where land Consolidation was applied in the Karacabey district of Bursa province in Turkey. In: International Congress on Agrarian Reform and Rural Development. Ankara Turkey September 1992, P.14.

Fan CS 2002. Child Labour and The Interaction between the Quantity and Quality of Child Labour. Lingnan University, Department of Economics, Working paper. Hong Kong, P. 25.

Glick P, Sahn D 2000. Schooling of girls and boys in a West African country: The effects of parental education, income and household structure. Economics of Education Review, 19(1): 63-87.

Grootaert C 1998. Child labour in Cote d'Ivoire: Incidence and determinants. Discussion Paper, Social Development Department. Washington D.C.: The World Bank.

ILO 1997. Bitter Harvest. Geneva: International Labour Organization ( ILO) P.17.

ILO 2002. Every Child Counts: New Global Estimates on Child Labour. ILO Report 23. Geneva: ILO.

Lavy V 1992. Investment in Human Capital: Schooling Supply Constraints in Rural Ghana. Living Standard Measurement Study Working Paper No. 93, World Bank, Washington D.C.: World Bank, P. 24.

NPC 2000. Population Estimates of Nigeria. The National Population Commission of Nigeria. Abuja: NPC, P. 3.

Ogunfowara O, Norman D 1974. Optimization model for evaluating the stability of sole cropping and mixed cropping system under changing resource and technical levels. Journal of Rural Sociology, 2(4): $31-38$.

Okoruwa V 1994. The Economics of Agropastoral Production System in the Derived Savanna of Oyo State, Nigeria. Ph.D Dissertation (Unpublished). University of Ibadan, Nigeria, P. 54.

Okuneye P A 1995. Nigeria Agriculture on the Run but Refuses to Move. $5^{\text {th }}$ Inaugural Lecture Series, University of Agriculture. Abeokuta, Nigeria. Nigerprint Lagos P. 8.

Oloruntimilehin O 2000. Farm Children, Child Abuse and Agricultural Production in Nigeria. In: SB Williams, A Jibowu, D Torimirs (Eds.): Farm Children and Agricultural Productivity in the $21^{\text {st }}$ Century. The $2^{\text {nd }}$ Annual Conference of Children in Agriculture. Programme (CIAP), P. 69. 